\title{
Real Concerns over COVID-19 Variants of Concern
}

\author{
Hatem Tallima, Rashika El Ridi* \\ Zoology Department, Faculty of Science, Cairo University, Giza 12513, Egypt
}

Address correspondence to: Rashika El Ridi, Zoology Department, Faculty of Science, Cairo University, Giza 12613, Email:rashika@sci.cu.edu.eg.

\section{Running Title: OPINION}

Keywords: SARS-CoV-2; Replication, Vaccines; Cytotoxic T cells; Variants of concerns,

\section{INTRODUCTION}

Severe acute respiratory syndrome corona virus (SARS-CoV)-2 obtained from patients infected despite being fully vaccinated with either BNT162b2 (Pfizer/BioNTech), mRNA-1273 (Moderna), or JNJ-78436735 (Janssen) showed increased mutations rates in the N-terminal domain (NTD) and receptor-binding domain (RBD) of the spike glycoprotein when compared with virus from unvaccinated controls (1). These changes are associated with immune evasion and diagnostic failures, prominent characteristics of variants of concern (2). Variants of concern (VOC) appeared to be overrepresented in numerous breakthrough infections of fully vaccinated people in the United States and (1,3-6), and Israel (7). These findings confirm concerns about the relation of SARS-CoV-2 variants with vaccine breakthrough, and urged us to attempt clarifying the likely link between vaccination with the currently used vaccines and VOC emergence.

\section{VIRUS REPLICATION IN IMMUNE CELLS}

Upon invasion of the nasopharynx and oral cavity, SARS-CoV-2 may be opsonized by complement components or antibody, and engulfed in immune cells, such as neutrophils, macrophages, and dendritic cells. The virus is endocytosed in the immune cells to be digested by endosomal or cytosolic enzymes, and peptides processed for presentation on the surface membrane, in association with HLA class II and class I molecules, ready to stimulate the generation of specific antibodies and cytotoxic $\mathrm{T}$ cells, while virus replication is abortive (8).

\section{VIRUS REPLICATION IN STRUCTURAL CELLS}

SARS-CoV-2 accesses epithelial cells in the tongue, salivary glands, and mucosal lining of respiratory and digestive tract via binding to the host cell receptor, angiotensin-converting enzyme $2(9,10)$. Virus load invading structural cells is met by the cytoplasmic innate immunity receptors, notably retinoic acid-inducible gene-I (RIG-1). Upon interaction with the viral genome, RIG-1 abrogates its very first replication steps, resulting into abortive infection $(11,12)$. Failure of the innate defense mechanisms (13) allows viral replication to completion, transport of the virions to the cell surface and release by exocytosis, usually followed by cell death apoptosis, necroptosis, and pyroptosis $(9,14-16)$. 


\section{IMMUNE RESPONSES IMPACT ON VIRUS REPLICATION IN STRUCTURAL CELLS OF UNVACCINATED HOSTS}

Before and concomitantly to virus multiplication in host structural cells, antibodies to viral proteins and glycoproteins are generated, and assist in preventing virus entry in more cells via agglutination, opsonization, complement activation, and neutralization of virions. Antibodies may also assist natural killer cells and macrophages in antibody-dependent cell-mediated cytotoxicity (ADCC) of infected cells displaying viral peptides on their surface membrane. Widespread lysis of such cells is achieved by cytotoxic T lymphocytes (17). Subsequent virus spread, release of danger-associated molecular patterns (DAMP), severe inflammatory reactions, and fulgurant cytokine storm affect the infected host. Lysis of virus-infected cells anytime in the midst of virion replication, virion assembly and exocytosis processes leads to the release of mature, immature, aberrant, and variant virions, which may threaten populations around (18-21). Such events, however, took place in only a fraction of the 200 million SARS-CoV-2 infected people, because the vast majority therefrom was able to restrict the infection, essentially relying on their efficient innate immunity responses $(13,17,22-24)$. Importantly, most, if not all, the 20 million worldwide who suffered severe disease (25) were hospitalized, confined, isolated, and prevented from delivering current or variant virions to the surrounding environment and people. Notwithstanding, several SARS-CoV-2 variants of interest and VOC emerged (26-28).

\section{IMMUNE RESPONSES IMPACT ON VIRUS REPLICATION IN STRUCTURAL CELLS OF FULLY VACCINATED HOSTS}

Immunization with the vaccines in world-wide trials (17) leads to generation of cytotoxic T cells specific to viral peptides in association with HLA class I molecules, and specific antibodies capable of mediating ADCC of cells that display relevant viral peptides on their surface. Upon SARS-CoV-2 infection of structural cells in the nasopharynx, memory cytotoxic $\mathrm{T}$ cells as well as antibodies are rapidly generated, bypass innate immune defenses, and besides hindering virus movement, they immediately proceed to killing of infected cells, not at the onset of replication of the viral genome, as for RIG-1, not at the completion of virion assembly as in unscathed cells, but anytime in the midst of the multiplication processes, entirely unpredictably and at random, generating the release of mature, immature, aberrant, and variant virions. Such events may take place in more than two billion vaccinated people who are living free of confinement and lockdown since they suffer only mild disease or are asymptomatic $(1-6 ; 25,26,29)$. The enormity of the number of individuals inoculated with the vaccines, continuous exposure to SARS-CoV-2, (1, 3-7), and energetic outdoors activities will centuplicate the probability of acquired immunity-generation and spread of further VOC (1-7).

\section{DISCUSSION}

The mounting immune pressure of humans led the SARS-CoV-2 virus to evolve variants less susceptible to antibody-mediated neutralization (29). Hence, access to the host structural cells is still permitted. Entry into immune cells is also preserved via complement activation, agglutination, and opsonization. Acquired immunity is fully activated leading to generation of antibodies, which fail to protect the host, yet synergize via ADCC with cytotoxic T cells to destruction of all cells harboring virus and expressing viral peptides on the their surface membrane, with release of immature and aberrant virions. The virus suffering from the 
inability of properly replicating may evolve or variant virions may emerge that preferentially, directly and rapidly target the immune-privileged sites of the brain, the anterior chamber of the eye, heart valves, and testes (30-33). It is best that humans never face such variant, which indeed should be named the omega $(\omega)$ variant. Accordingly, it is recommended to refrain from using the available vaccines $(34,35)$ and only rely on the spike glycoprotein subunit 1 in a protein form (17) for vaccination of individuals with underlying morbidities, advanced age, and at serious risk.

\section{REFERENCES}

1. Duerr R, et al. Dominance of alpha and Iota variants in SARS-CoV-2 vaccine breakthrough infections in New York City. J Clin Invest (2021)152702. doi: 10.1172/JCI152702.

2. Shahhosseini N, Babuadze GG, Wong G, Kobinger GP. Mutation signatures and in silico docking of novel SARS-CoV-2 variants of concern.

Microorganisms (2021) 9(5):926. doi: 10.3390/microorganisms9050926

3. McEwen AE, Cohen S, Bryson-Cahn C, Liu C, Pergam SA, Lynch J, et al. Variants of concern are overrepresented among post-vaccination breakthrough infections of SARS-CoV-2 in Washington State. Clin Infect Dis (2021) ciab581. doi: 10.1093/cid/ciab581

4. Hacisuleyman E, Hale C, Saito Y, Blachere NE, Bergh M, Conlon EG, et al. Vaccine breakthrough infections with SARS-CoV-2 variants. N Engl J Med (2021) 384(23):2212-2218. doi: 10.1056/NEJMoa2105000

5. West AP Jr, Wertheim JO, Wang JC, Vasylyeva TI, Havens JL, Chowdhury MA, et al. Detection and characterization of the SARS-CoV-2 lineage B.1.526 in New York. Nat Commun (2021) 12(1):4886. doi: 10.1038/s41467-02125168-4

6. Brown CM, Vostok J, Johnson H, Burns M, Gharpure R, Sami S, et al.. Outbreak of SARS-CoV-2 infections, including COVID-19 vaccine breakthrough infections, associated with large public gatherings - Barnstable County, Massachusetts, July 2021. MMWR Morb Mortal Wkly Rep (2021) 70(31):1059-1062. doi: 10.15585/mmwr.mm7031e2

7. Kustin T, Harel N, Finkel U, Perchik S, Harari S, Tahor M, et al. Evidence for increased breakthrough rates of SARS-CoV-2 variants of concern in BNT162b2-mRNA-vaccinated individuals. Nat Med (2021) 27(8):1379-1384. doi: 10.1038/s41591-021-01413-7

8. Zheng J, Wang Y, Li K, Meyerholz DK, Allamargot C, Perlman S. Severe acute respiratory syndrome coronavirus 2-induced immune activation and death of monocyte-derived human macrophages and dendritic cells. J Infect Dis 2021) (223:785-795, doi: 10.1093/infdis/jiaa753.

9. Brandão TB, Gueiros LA, Melo TS, Prado-Ribeiro AC, Nesrallah ACFA, Prado GVB, Santos-Silva AR, Migliorati CA. Oral lesions in patients with SARS-CoV-2 infection: could the oral cavity be a target organ? Oral Surg Oral Med Oral Pathol Oral Radiol (2021) 131(2):e45-e51. doi: 10.1016/j.oooo.2020.07.014

10. 10. Qian Q, Fan L, Liu W, Li J, Yue J, Wang M, Ke X, Yin Y, Chen Q, Jiang C. Direct evidence of active SARS-CoV-2 replication in the intestine. Clin Infect Dis (2021) 73(3):361-366. doi: 10.1093/cid/ciaa925 
11. Yamada T, Sato S, Sotoyama Y, Orba Y, Sawa H, Yamauchi H, Sasaki M, Takaoka A.RIG-I triggers a signaling-abortive anti-SARS-CoV-2 defense in human lung cells. Nat Immunol (2021) 22(7):820-828. doi: 10.1038/s41590-021-00942-0

12. Yang D, Geng T, Harrison AG, Wang P. Differential roles of RIG-I-like receptors in SARS-CoV-2 infection. bioRxiv (2021) Feb 11:2021.02.10.430677. doi: 10.1101/2021.02.10.430677. Preprint.

13. Ziegler CGK, Miao VN, Owings AH, Navia AW, Tang Y, Bromley JD, et al. Impaired local intrinsic immunity to SARS-CoV-2 infection in severe COVID19. Cell (2021) S0092-8674(21)00882-5. doi: 10.1016/j.cell.2021.07.023

14. Wang Y, Grunewald M, Perlman S. Coronaviruses: an updated overview of their replication and pathogenesis. Methods Mol Biol (2020) 2203:1-29. doi: 10.1007/978-1-0716-0900-2_1

15. V'kovski P, Kratzel A, Steiner S, Stalder H, Thiel V. Coronavirus biology and replication: implications for SARS-CoV-2. Nat Rev Microbiol (2021) 19(3):155-170. doi: 10.1038/s41579-020-00468-6

16. Paolini A., Borella R., De Biasi S., Neroni A., Mattioli M., Lo Tartaro D.et al. Cell death in coronavirus infections: uncovering its role during COVID-19. Cells (2021) 10(7):1585. doi: 10.3390/cells10071585

17. Tallima H, El Ridi R. SARS-COV-2 Vaccines Immunological Impact. Authorea. July 26, 2021. doi: 10.22541/au.162731253.34527848/v1

18. Korber B, Fischer WM, Gnanakaran S, Yoon H, Theiler J, Abfalterer W, et al. Tracking changes in SARS-CoV-2 Spike: Evidence that D614G increases infectivity of the COVID-19 virus. Cell (2020) 182(4):812-827.e19. doi: 10.1016/j.cell.2020.06.043

19. Long SW, Olsen RJ, Christensen PA, Bernard DW, Davis JJ, Shukla M, et al. Molecular architecture of early dissemination and massive second wave of the SARS-CoV-2 virus in a major Metropolitan area. mBio (2020) 11(6):e0270720. doi: $10.1128 / \mathrm{mBio} .02707-20$

20. Plante JA, Liu Y, Liu J, Xia H, Johnson BA, Lokugamage KG, et al. Spike mutation D614G alters SARS-CoV-2 fitness. Nature 2021 Apr;592(7852):116121. doi: 10.1038/s41586-020-2895-3

21. Tang JW, Tambyah PA, Hui DS. Emergence of a new SARS-CoV-2 variant in the UK. J Infect (2021) 82(4):e27-e28. doi: 10.1016/j.jinf.2020.12.024

22. Amor S, Fernández Blanco L, Baker D. Innate immunity during SARS-CoV-2: evasion strategies and activation trigger hypoxia and vascular damage. Clin Exp Immunol (2020) 202(2):193-209. doi: 10.1111/cei.13523

23. Netea MG, Giamarellos-Bourboulis EJ, Domínguez-Andrés J, Curtis N, van Crevel R, van de Veerdonk FL, Bonten M. Trained immunity: a tool for reducing susceptibility to and the severity of SARS-CoV-2 infection. Cell (2020) 181(5):969-977. doi: 10.1016/j.cell.2020.04.042

24. Golonka RM, Saha P, Yeoh BS, Chattopadhyay S, Gewirtz AT, Joe B, Vijay-Kumar M. Harnessing innate immunity to eliminate SARS-CoV-2 and ameliorate COVID19 disease. Physiol Genomics (2020) 52(5):217-221. doi: 10.1152/physiolgenomics.00033.2020

25. World Health Organization. Coronavirus disease (COVID-19) Weekly Epidemiological Update and Weekly Operational Update. https://www.who.int/emergencies/diseases/novel-coronavirus-2019/situation-reports

26. CCEC. Centers for Disease Control and Prevention. What you need to know about variants. https://www.cdc.gov/coronavirus/2019-ncov/variants/variant.html 
27. Tegally H, Wilkinson E, Giovanetti M, Iranzadeh A, Fonseca V, Giandhari J, et al. Detection of a SARS-CoV-2 variant of concern in South Africa. Nature (2021) 592(7854):438-443. doi: 10.1038/s41586-021-03402-9

28. Tegally H, Wilkinson E, Lessells RJ, Giandhari J, Pillay S, Msomi N, et al. Sixteen novel lineages of SARS-CoV-2 in South Africa. Nat Med (2021) 27(3):440-446. doi: 10.1038/s41591-021-01255-3

29. Geers D, Shamier MC, Bogers S, den Hartog G, Gommers L, Nieuwkoop NN, et al. SARS-CoV-2 variants of concern partially escape humoral but not T-cell responses in COVID-19 convalescent donors and vaccinees. Sci Immunol (2021) 6(59):eabj1750. doi: 10.1126/sciimmunol.abj1750

30. Forrester JV, McMenamin PG, Dando SJ. CNS infection and immune privilege. Nat Rev Neurosci (2018) 19(11):655-671. doi: 10.1038/s41583-018-0070-8.

31. Hill MA, Kwon JH, Gerry B, Hardy WA, Walkowiak OA, Kavarana MN, Nadig SN, Rajab TK. Immune privilege of heart valves. Front Immunol (2021) 12:731361. doi: 10.3389/fimmu.2021.731361.

32. Jashari R, Van Esbroeck M, Vanhaebost J, Micalessi I, Kerschen A, Mastrobuoni S. The risk of transmission of the novel coronavirus (SARS-CoV2) with human heart valve transplantation: evaluation of cardio-vascular tissues from two consecutive heart donors with asymptomatic COVID-19. Cell Tissue Bank. (2021) 9:1-10. doi: 10.1007/s10561-021-09913-z.

33. Eleiwa T, Abdelrahman SN, ElSheikh RH, Elhusseiny AM. Orbital inflammatory disease associated with COVID-19 infection. J AAPOS (2021) S1091-8531(21)00100-2. doi: 10.1016/j.jaapos.2021.04.002

34. Rijkers GT, Weterings N, Obregon-Henao A, Lepolder M, Dutt TS, van Overveld FJ, Henao-Tamayo M. Review: Antigen presentation of mRNA-based and virus-vectored SARS-CoV-2 vaccines. Vaccines (2021) 9(8):848. doi:10.3390/vaccines9080848

35. Xia S, Zhang Y, Wang Y, Wang H, Yang Y, Gao GF, et al. Safety and immunogenicity of an inactivated SARS-CoV-2 vaccine, BBIBP-CorV: a randomised, double-blind, placebo-controlled, phase 1/2 trial. Lancet Infect Dis (2021) 21(1):39-51. doi: 10.1016/S1473-3099(20)30831-8

Conflict of interest: The authors certify that they have no affiliations with or involvement in any organization or entity with any financial or non-financial interest in the subject matter or materials discussed in this article. 